The Journal of International Lingual, Social and Educational Sciences Year: 2019, Volume: 5, Number: 1

DOI:1034137/jilses.505073

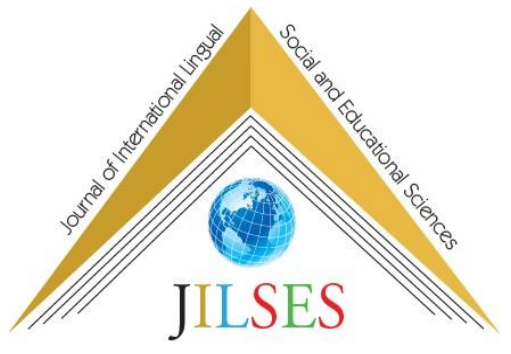

\title{
8. Sınıf Türkçe Dersi Merkezî Sınav Sorularının PISA Okuma Becerileri Yeterlilikleri Açısından İncelenmesi ${ }^{1}$
}

\begin{abstract}
Salih Tuzlukaya ${ }^{2}$
$\ddot{O}_{\text {zet }}$

PISA araştırmasında okuma becerileri; "kişinin topluma katılmak, potansiyelini ve bilgisini geliştirmek ve amaçlarını gerçekleştirmek için yazılı metinleri anlaması, kullanması, onlar üzerinde düşünmesi ve onlarla uğraşması" olarak tanımlanmaktadir.

Bir dil ve beceri eğitimi olan Türkçe ögrretiminde ögrrencilerin metni anlamalarl, öğrenme sürecine aktif olarak katılmaları, metni çözümlemeleri, eleştirel düşünme becerilerini aktif olarak kullanabilmeleri ancak metni oluşturan tüm parçaların bütün olarak ele alınmasıyla mümkün olacaktır. Böyle bir yaklaşımla Türkçe derslerinin işlenmesi, ögrencilerin metni gerçekten analiz etmelerini, anlamlandırmalarını ve metni bir bütün olarak parçalarıyla ve parçaların birbirleriyle olan ilişkilerini kavramalarına yardımcı olacaktır.

$B u$ veriler doğrultusunda, yapılan son PISA araştırmasında okuma becerileri alanında ve temel eğitimden ortaöğretime geçişte büyük bir paya sahip 8. Sinıflar Merkezi Sinavlarda Türkçe dersindeki öğrencilerin başarısız olma nedenleri düşünüldügünde "okuryazarlık" becerilerinin öğrencilerde eksik olduğu görülmektedir. Bu sebeple, MEB tarafindan hazırlanan temel eğitimden ortaögretime geçişte uygulanan 8.Sinuf Türkçe Dersi Merkezî Sınav soruları ve soruların dayanağı olan kazanımlar, PISA yeterliliklerine göre yeniden gözden geçirilmeli ve yapılandırılmalıdır. Bu bağlamda 8. Sinıf Türkçe Öğretim Programı'ndaki okuma alanı ile ilgili kazanımlarla PISA yeterlilikleri karşılaştırıldığında Türkçe dersi kazanımlarının daha çok alt düzey becerileri gerçekleștirmeye yönelik olduğu sonucu ortaya çıkmaktadır. O halde Türkçe dersi kazanımlarının ve sorularının PISA okuma becerileri değerlendirme çerçevesine göre daha üst düzey becerileri ölçebilecek niteliğe çıkarılması uygun olacaktır.
\end{abstract}

Anahtar Kelimeler: PISA, 8. Sinıf Türkçe Dersi Ortak Sınav, Okuma Becerileri, Okuduğunu Anlama

\section{8th Class Turkish Lessons Exam Questions Examined in Regard to PISA Reading Sufficiency Skills}

\begin{abstract}
The PISA survey of reading skills; "to participate in society a person's potential to accomplish their goals and improve the understanding of written texts knowledge and use to deal with them and consider them" is defined as. Skills training in the teaching of the Turkish language and the students understand the text, to take an active role in the learning process, text analysis, but text to actively use critical thinking skills when considered as a whole comprise all of the parts that will be possible. With such an approach in the processing of Turkish lessons, the students really analyze the text, the ability to understand and teach the text as a whole and its parts and the parts will help to understand their relationship with each other. These data are in line with the recent PISA survey of reading skills from basic education to secondary education in the field and has a large share in the transition 8. The exam center classes in a course in Turkish students 'failure causes when considering "literacy" skills of students that is missing in it is observed. For this reason, prepared by the Ministry of education, from basic education to secondary education is applied in the transition 8.Class Turkish Center Lessons, exam questions and the questions which forms the basis of the gains, according to the Pisa competencies should be revised and must be configured. 8 in this context. Turkish class Turkish lessons with the acquisitions of the course competencies in the PISA comparison in the lower level of achievements more than lower-level skills to perform it has been concluded that. Then a Turkish course, reading skills and problems achievements according to PISA assessment framework, higher-level skills will be appropriate to measure the quality of when is to be removed.
\end{abstract}

Key words: PISA, 8. Class Turkish Lessons Common Exams, Reading Skills, Reading Comprehension

\footnotetext{
${ }^{1}$ Bu makale I. Uluslararası Türk Dili ve Bilgi Şöleni’nde (Erzurum, 2017) sunulan sözlü bildirinin genişletilmiş hâlidir.

${ }^{2}$ Okutman, Kudüs Üniversitesi, salih_tuzlukaya@hotmail.com, http://orcid.org/0000-0002-6528-4126
} 


\section{Giriş}

Değişen ve gelişen dünyada birey davranışlarındaki değişiklikleri kalıcı hale getirebilmek dünyadaki gelişmelere ayak uydurabilen, çağın beklentilerine cevap verebilen, araştıran, sorgulayan ve kendini gerçekleştirmiş, özgüven duygusu gelişmiş bireyler yetiştirmek ancak eğitimle mümkün olmaktadır. Öğrencilerin başarı düzeylerini artırmak, eğitim politikalarının öğrenci üzerindeki etkisini görmek, eğitim sistemini daha işlevsel hale getirebilmek, eğitim kalitesini yükseltmek için ülkeler olarak birtakım uluslararası değerlendirme çalışmalarına katılmaktadırlar. TIMSS, PIRLS ve PISA gibi uluslararası değerlendirme çalışmaları, ülkelerarası bir yarışma niteliğinde olmayan, katılan ülkelerin kendi eğitim sistemlerini değerlendirmelerini, öğrencilerin matematik okuryazarlı̆̆ yıllara göre takip edilmesini sağlayan araştırmalardır.

Eğitim organizasyonu OECD ( Ekonomik İş Birliği ve Kalkınma Teşkilatı)'nin yürüttüğü PISA araştırması, öğrencilere bilgi aktarmayla birlikte, bu bilgileri günlük hayatta kullanma ve karşılaşılan problem durumlarında çözüm üretme ve yeni yaşantılara aktarma gibi hedeflerini öğretim programlarında, yöntemlerde, tekniklerinde ve ölçme değerlendirme süreçlerindeki güncelleme ve değişikliklerde önemli bir kriter kabul edilmektedir.

Hedefinde temel eğitimi tamamlamış öğrenci grubu olan sonuncusu 2015 yılında yapılmış ve son on yedi yıldır üç yıl arayla yapılan PISA projesi, dünya ülkelerinin OECD üyesi ülkelerle birlikte yaklaşık \%90'ı kapsayan zorunlu eğitim öğretimini tamamlayan öğrencilerin hayatta uygun bir statü için belirleyebilmek için ana hedef ve becerileri ne düzeyde kazandıklarını değerlendirmeyi amaçlamaktadır (MEB 2016). Ülkemizde sınıf seviyesi olarak ortaokul 7 ve daha yukarı sınıf seviyelerindeki 15 yaş grubu öğrencilerinin değerlendirmeye alındığı bu proje, "okuryazarlık" ana teması çerçevesinde okuma becerileri, matematik ve fen alanlarında öğrencilerin yeterliliklerini ölçmektedir.

PISA'da okuryazarlık teması ile temel beceri alanlarındaki farklı problem durumlarında, problemin tanınması, anlaşılması ve çözülmesi ile mevcut bilginin problem durumuna aktarılması, analitik değerlendirilme yapılması, gerekçelendirme ve sosyal iletişim becerileri kurulması kastedilmektedir (MEB, 2016).

Okuma becerileri PISA'da; "bireyin sosyalleşmek, mevcut bilgilerini artırmak ve hedeflerine ulaşmak için her türlü metni okuması, anlamlandırması, yorumlaması ve metin üzerinde çıkarım yapabilmesi olarak tanımlanır (MEB, 2016). Okumayı bir beceri olarak tanımlayan bu ifade, kalıplaşmış okuma ve anlamanın çok daha fazlasını kapsamaktadır. Kapsam olarak bakıldığında PISA'da okuma becerisi, bireylerin karşılaş̧ıkları basılı ya da elektronik ortamdaki metinler ile kullanmalık ve işlevsel olan bilgileri düşünme yoluyla yüzeysel anlamadan daha çok derinlemesine çözümleyerek okuyucunun metne yaklaşımını ve metni kullanabilme becerisini içine alır.

PISA projesinde okuma becerileri değerlendirme çerçevesi, birbirleriyle ilişkili üç temel bölüm içinde incelenmektedir. Bunlar metnin kendisi, okurun metne yaklaşımı ve metnin kullanım amacıdır (MEB, 2010). Bu değerlendirme çerçevesinde metin ile kastedilen metnin sunumu, metnin sinırlılığı, metnin şekli ve metnin türüdür. Okuyucunun metne yaklaşımı, bilgiye erişme ve bilgiyi hatırlama, bilgileri birleştirme ve çözümleme, okuyucunun metninle ilgili düşüncelerini açıklama ve değerlendirme biçiminde üç biçimde kategorize edilmiştir. PISA değerlendirmesinde kullanılan üçüncü temel özellik, Metnin kullanım amacı, PISA araştırmasında yer alan üçüncü değerlendirme kriteri, metnin kullanımıdır. Metnin hangi amaçla yazıldığını belirten özellik metnin kullanım amacıdır. PISA araştırmasında metnin kullanılma amacı, diğer iki değerlendirme ölçeğine göre daha az etki sağladığı için rapor kısmında kullanılmamaktadır. Menin içeriği; sonuç raporlarını belirtmek için değil; PISA'da kullanılan okuma metinlerinin türlerinin çeşidini fazlalaştırmak için kullanılmaktadır. Okuma becerilerinin kapsamını genişletmek için metnin hangi amaçla yazıldığının tespit edilmesi gerekmektedir. Bu sayede, kelime, gramer ve bununla ilgili yapı ve özellikler, ölçme ve değerlendirmeye etkinliklerinde kullanılabilir (MEB, 2010).

PISA'da okuma becerisi ilk uygulama olan 2000 ve 2009 yıllarında temel ölçülen yeterlilik alanı olmuştur. Okuma becerisi alanında, öğrencilerin günlük yaşamlarında yüz yüze gelebilecekleri durum ve olaylarda yazılı metinlerden yararlanma yeterlilikleri ölçülmeye çalışılmaktadır. Araştırmada öğrencilerden beklenen farklı metin türlerinde yer alan bilgi ve görüşleri yüzeysel yorumlama değil, metni anlama ve çözümlemedir. Metinde yer alan bilgiyi tespit etmek, metni çözümlemek, metinden hareketle metni değerlendirmek ve yorumlamak gibi becerilerin öğrenciler tarafından kazanılması beklenmektedir. 2009 yılından önce belirlenen okuma becerilerine ait 5 yeterlilik düzeyine 2009 yılından itibaren daha üst düzey olan 6. yeterlilik düzeyi eklenmiştir. 6. düzeye uygun olarak bu yeterliği değerlendiren yeni soru maddeleri eklenmiştir. Ayrıca 2009 yılından önce en düşük yeterlik seviyesi olan 1. yeterlik düzeyi, 1a yeterlik düzeyi şeklinde değiştirilmiş olup bu seviyenin daha altında kalan öğrencileri belirlemek amacıyla $1 \mathrm{~b}$ yeterlik düzeyi eklenmiştir. $\mathrm{Bu}$ en alt yeterlik düzeyi olan $1 \mathrm{~b}$ düzeyindeki öğrencileri belirmek için 2009 yılından itibaren zorluk düzeyi daha düşük sorulara yer verilmiş ve diğer yeterlik düzeylerinde farklı bir değişikliğe gidilmemiştir (MEB, 2010). 
2003 yılında uygulanan PISA sonuçlarına göre okuma becerileri alanında Türkiye'deki öğrencilerinin üçte ikisinden fazlası (\%67,7) ikinci düzey ve daha alt düzeyde kalmıştır (MEB, 2005). 2006 yılında bu oran \%63,2, (MEB, 2010) 2009 yllında \%56,7, (MEB, 2010) PISA 2012'de \% 52,5 (MEB, 2015 a) olduğu tespit edilmiştir. Ancak PISA 2015'de tekrar yükselerek \%72,6'ya (MEB, 2016) kadar çıkmıştır. Bununla birlikte 2003 yılındaki PISA sonuçlarına göre okuma becerileri alanında Türkiye'deki öğrencilerin \%3,8'i (MEB, 2005), 2006 yılında \% 2,10'u (MEB, 2010) ve 2009 yılında \%1,8'i 5. yeterlik düzeyinde olduğu belirtilmiștir. 2009 y1lında düzenlenen PISA araştırma sonuçlarına göre ise Türkiye'deki hiçbir öğrenci 6. yeterlik düzeyine ulaşamamış; 2012 yılında ise bu düzeyde sadece $\% 1,1^{\prime}$ 'lik bir oran ve PISA 2015 'te bu oranın $\% 0,7$ olduğu dikkat çekmektedir (MEB, 2016). 2006, 2009 ve 2012 PISA araştırmalarında, alt düzeyde yer alan öğrenci sayısında azalma olduğu fakat 2015 yıllında temel yeterlik düzeyinin altındaki öğrenci sayısının arttığı görülmektedir. 2006, 2009 ve 2012 yıllarında okuma becerileri puanlarında artma olduğu fakat daha üst düzey olan $4,5,6$. yeterlik düzeylerinde yer alan öğrenci sayılarında azalma olduğu tespit edilmiştir.

Millî Eğitim Bakanlığı tarafindan düzenlenen Türkçe Öğretim Programlarında Türkçe öğretiminin amaçları irdelendiğinde, dil becerilerinin öğretilmesi, dilin sözcük dağarcığının ve dilbilgisi yapısının öğretilmesi ve bilimsel, eleştirici, doğru, yapıcı ve yaratıı düşünmenin öğretilmesi gibi dil ediminin yukarıda sözü edilen her iki amacını da kapsayan bir açıklamayla karşılaşılmaktadır. Amaç belirlenmesinde göz ardı edilen bir maddenin olmadığı düşüncesi, öğrencilerin Türkçeyi istenilen düzeyde kullanmamalarının nedeninin yöntem ve öğretim tekniklerinin seçimi ya da içerik ve uygulamaya yönelik eksiklik ya da yetersizlik bağlamında aranması gerekliliğini ortaya çıkarır.

Dil öğretiminde nesne dildir, amaç dilsel iletişim kurmayı gerçekleştirebilmektir. Bu amaç doğrultusunda özellikle yöntem bağlamında çalışmalar ve araştırmalar yapılmaktadır. Dil öğretimi, disiplinlerarası bir çalışmayı gerektirdiğinden yalnızca dilbilim ile değil, diğer bütün bilimlerle ortak çalışmayı gerektirir. Kocaman'ın (1996) "Anadili ögretimi dilbilim, ruhbilim, toplumbilim, felsefe, tutumbilim (ekonomi), bilişi̇m gibi alanların kesiştiği bir etkinlik alanıdır. Anadili olarak Türkçe öğretimindeki başarısızlık biraz da konuyu bu bütünlük içinde görememekten ileri gelmektedir." şeklindeki tespiti Türkçe öğretimindeki başarısızlığın biraz da disiplinlerarası bakışın eksikliğinden kaynaklandığını göstermektedir.

Bugün Türkçe öğretiminin salt yazın metinleriyle ve geleneksel dilbilgisi konularıyla sınırlanması, Türkçe öğretimini zoraki yapılan, biçimci bir etkinlik düzeyine indirgediği bir gerçektir. Dilidüzgün'e göre (2008) "Anadili olarak Türkçeyi öğretmek için kullanılan ders kitaplarında dilin en güzel örneklerini sergiledikleri için yazınsal metinler neredeyse kitabın tamamını oluşturan metin türleridir. Oysa öğrenciler bir şikâyet mektubu yazabilmeli, bir tartışmaya girebilmeli, gazete ve televizyondaki reklam ve haber metinlerini anlayabilmeli, aynı şekilde bunlar gibi çeşitli söylem tiplerini kendileri de oluşturabilmelidir."

Ülkemizde Türkçe derslerinde kullanılan yöntem ve tekniklerin hem Türkçe Öğretim Programı'ndaki okuma alanına ait kazanımların gerçekleştirilmesinde hem de PISA araştırmasında okuma becerileri ile ilgili yeterlilikleri sağlamada eksik kaldığı görülmektedir. Bu sebeple Türkçe Dersi Öğretim Programı 2015 yılında eğitim alanındaki yeni yönelimler ve yaklaşımların etkisiyle ve uluslararası düzeyde yapılan değerlendirmeler neticesinde güncellenmiş ve son olarak 2017 yılında tüm sınıf ve derslerde olduğu gibi Türkçe Dersi Öğretim Programı'nı ve bu programın devamı niteliğinde olan Türk Dili Edebiyatı Dersi Programı'nı özellikle uluslararası platformda birtakım ölçme ve değerlendirmeler neticesinde taslak olarak belirlemiştir. Türkçe Dersi Taslak Programı'nda yer alan kazanımlar, PISA Okuma Becerileri Değerlendirme Çerçevesi'ne dayanarak belirlenen Okuma Becerileri Yeterlik Düzeylerinin Özet Tanımları'na uygun olarak güncellenmiştir (MEB, 2017).

Millî Eğitim Bakanlığı son yıllarda temel eğitim ve ortaöğretim programlarının değiştirilmesinin yanında ortaöğretime geçiş sisteminde de değişiklikler yapmıştır. Daha önce uygulanmakta olan Ortaöğretim Kurumlarına Öğrenci Seçme Sınavı (OKS) yerine Ortaöğretime Geçiş Sistemi kapsamında Seviye Belirleme Sınavı getirilmiştir. Seviye Belirleme Sınavı'nda OKS'den farklı olarak yabancı dil sorularına da yer verilmişsir. Son olarak, 2013-2014 öğretim yılından başlayarak altı temel ders için 8.sınıfta öğretmen tarafindan dönemsel olarak yapılan sınavlardan bir tanesinin ortak olarak gerçekleştirilmesine karar verilmiştir. Ortak sınavlarda, SBS'den farklı olarak Din Kültürü ve Ahlâk Bilgisi dersi sınav kapsamına alınmıştır.

8. Sınıf Merkezî Ortak sınavlar, altı temel ders için 8. sınıfta öğretmen tarafından dönemsel olarak yapılan sınavlardan, iki yazılısı olan derslerden birincisi, üç yazılısı olan derslerden ikincisi olmak üzere yılda iki defa yapılmaktadır. Ortak sınavlar, 8.sınıf Türkçe, Matematik, Fen ve Teknoloji, Din Kültürü ve Ahlak Bilgisi, T.C. İnkılâp Tarihi ve Atatürkçülük ile Yabancı Dil derslerinden yapılır. Sınav soruları, 8. sınıf Türkçe, Matematik, Fen ve Teknoloji, Din Kültürü ve Ahlak Bilgisi, T.C. İnkılâp Tarihi ve Atatürkçülük ile Yabancı Dil derslerinin öğretim programları esas alınarak hazırlanır. Sorular, sınavların yapılacağı tarihe kadar işlenen öğretim programlarının belirlenen kazanımları esas alınarak öğrencinin eleştirel düşünme, analiz yapma, problem çözme, sonuç çıkarma, yorumlama ve benzeri becerilerini ölçecek nitelikte hazırlanmaktadır.(MEB, 2014). 
Bu araştırma, aslında PISA projesi ile 8. Sınıf Merkezî Ortak Sınavların bir karşılaştırılması değildir. Yapılış amacı ve özellikleri birbirinden farklı olan sınavların metin ve soruları üzerinden geliştirilen değerlendirme araçlarına göre bir nitelik çözümlemesi yapılmıştır. Uluslararası kabul gören PISA araştırmasındaki metinlerin özellikleri, değerlendirme çerçevesi ve okuma becerileri yeterlikleri esas alınarak 8. Sınıf Türkçe Dersi Merkezî Ortak Sınav Sorularının nitelikleri belirlenmeye çalışılmıştır.

\section{Çalışmanın Amacı}

Araştırmanın amacı, Temel eğitimden ortaöğretime geçişte uygulanan 8. Sınıf Türkçe Dersi Merkezî Sınav sorularının PISA araştırmasındaki okuma becerileri yeterlilik düzeylerine ne derece uygun olduğunu ortaya koymaktır. Bu araştırma neticesinde PISA sınavı ile aynı yaş grubundan yüz binlerce temel eğitim son sınıf öğrencisinin katıldığı 8. Sınıf Merkezî Ortak Sınavı'nın, ülke genelindeki eğitim politikası ve durumu hakkında veri sağlayacak nitelikte düzenlenmesi gerektiğini ortaya koymak temel amaçtır.

\section{Yöntem}

Bu çalışma, betimsel (tarama) bir çalışma olup doküman analizine dayalı olarak yapılmıştır. Tarama modelinde araştırmaya konu olan olay, birey ya da nesne kendi durumu içinde ve olduğu gibi betimlenmeye çalışılır (Karasar, 2012: 77) Doküman analizi tek başına bir araştırma deseni olabildiği gibi, diğer desenlerle birlikte kullanıldığ durumlarda ek bilgi kaynağı olarak da kullanılabilmektedir (Yıldırım ve Şimşek, 2011: 187). PISA okuma becerileri yeterlilik düzeylerine göre analizlerin yapıldı̆̆ı tarama modelinde, 8. Sınıf Türkçe Dersi Merkezî Sınav soruları betimsel olarak düzenlenmiştir.

\section{Örneklem}

Bu çalışmada, 2013 yılından itibaren uygulanan 8. Sınıf Merkezî Ortak Sınavlardan en son gerçekleştirilen 20162017 Eğitim Öğretim Yılı II. Dönemi’ndeki 8. Sınıf Türkçe Dersi Merkezî Sınavı'nda sorulan toplam 15 soru doküman olarak incelenmiş, sorular değerlendirme araçları ve uzman görüşleri doğrultusunda çözümlenmiştir. Diğer yıllarda yapılan ortak sınavlardaki sorular, son yılda yapılan ortak sınav ile aynı kazanımları ve becerileri ölçtüğünden değerlendirmeye alınmamıştır.

\section{Veri Toplama Araçları}

Çalışma sürecinde 2016-2017 Eğitim Öğretim Yılı II. Dönemi’ndeki 8. Sınıf Türkçe Dersi Merkezî Sınav soruları, ilgili literatür taranarak uzman görüşüne başvurularak hazırlanan "Soru Analiz Listesi” ile incelenmiştir. Soru Analiz Listesi üç formla oluşturulmuştur:

\section{$>\quad$ "Soru Analiz Listesi 1" incelenen soruda yer alan metnin nasıl sunulduğunu,(şekli)}

türü)

"Soru Analiz Listesi 2" incelenen soruda yer alan metnin edebi yapısının ne olduğunu, (metnin

"Soru Analiz Listesi 3" incelenen soruda yer alan metne öğrencinin nasıl yaklaşacağını ve soru düzeylerini PISA değerlendirme çerçevesine göre belirlemek için geliştirilmiştir.

“Soru Analiz Listesi” oluşturulurken öncelikle üç Türkçe öğretmeni, PISA araştırması ile ilgili yayımlanan rapor ve örnek sınav sorularını incelemiştir. 2009 yılında yapılan PISA araştırmasının odak noktası "okuma becerileri” alanı olduğundan MEB'in PISA 2009 Ulusal Ön Raporu ve örnek sınav soruları, soru düzeyleri ve düzeyleri belirleyici ipuçları her araştırmacı tarafından ayrı ayrı incelenmiştir. İnceleme sonucunda, Çalışma için kullanılan“ Soru Analiz Listesi” PISA okuma becerileri örnek sınav soruları, sınav raporları ve öğrenci yeterlilik seviyelerine göre hazırlanmıştır. Bu araştırma sırasında, PISA okuduğunu anlama düzeylerinin neye göre belirlendiğini ve sınav sorularının hangi kategorilerde ne tür becerileri ölçmek için oluşturulduğunu belirten kısımları üzerinde ayrica durulmuştur.

\section{Verilerin Analizleri}

Verilerin analizi için 2016-2017 Eğitim Öğretim Y1lı II. Dönemi’nde uygulanan 8. Sınıf Türkçe Dersi Merkezî Sınav soruları tek tek incelenerek örnekleme alınacak soruların PISA okuma becerileri yeterlilik düzeylerine göre incelenebilecek nitelikte olanları belirlenmiştir. Veri olarak kullanılabilecek sorularda PISA "okuma becerileri” alanına girmeyen noktalama, yazım kuralları ve dilbilgisini ölçen sorulara yer verilmemiştir. Alan uzmanları ile birlikte her bir soru ile ilgili “Soru Analiz Listesi” üzerinde işaretlenmeleri yapılmış, çıkan farklı değerlendirmeler, değerlendirme ipuçları kullanılarak ve farklılıklar üzerinde tartışmalar sonucunda ortak bir görüşe varılmak suretiyle PISA okuduğunu anlama yeterliliklerine göre çözümlemeleri yapılmış ve yorumlanmıştır. Sorular tek tek incelenerek önce "Soru Analiz Listesi 1"e göre incelenmiş, sonra "Soru Analiz Listesi 2"ye göre metinler türlerine göre sınıflandırılmış ve her bir soru için frekans (f) ve yüzde (\%) değerleri bulunmuştur. Aynı şekilde "Soru Analiz Listesi 3"te de öğrencinin metne yaklaşımına göre sorular sınıflandırılmış ve soru düzeylerinin bu yaklaşımlara göre frekans (f) ve yüzde (\%) değerleri tespit edilmiştir. 


\section{Bulgu ve Yorumlar}

Çalışmanın bulguları aşağıda gösterilmiştir. Tablo 1'de 2016-2017 Eğitim Öğretim Yılı II. Dönemi'ndeki 8. Sınıf Türkçe Dersi Merkezî Sınav Soruları'nın metnin sunulma şekline göre dağılımı verilmiştir. Tablo 2'de 2016-2017 Eğitim Öğretim Yılı II. Dönemi’ndeki 8. Sınıf Türkçe Dersi Merkezî Sınav Soruları'nın metin türlerine göre dağılımı gösterilmiştir. Tablo 3'te ise 2016-2017 Eğitim Öğretim Yılı II. Dönemi’ndeki 8. Sınıf Türkçe Dersi Merkezî Sınav Soruları'nın öğrencinin metne yaklaşımına ve düzeylerine göre dağılımı verilmiştir.

Tablo 1 : 2016-2017 Eğitim Öğretim Yılı II. Dönemi 8. Sınıf Türkçe Dersi Merkezî Sınav Sorularının Metnin Sunulma Şekline Göre Dağılımı

\begin{tabular}{l|c|c}
\hline \multicolumn{1}{c}{ Soru Analiz Listesi 1 } \\
\hline Metnin Şekli & f & \% \\
\hline Akııı Metin (Cümle, Paragraf) & 15 & 100 \\
\hline Bağımsız Metin (Liste, Grafik, Tablo) & - & - \\
\hline Karışık Metin (Akıcı, Bağımsız ) & - & - \\
\hline
\end{tabular}

Tablo 1 incelendiğinde, 8. Sınıf Türkçe Dersi Merkezî Sınav Sorularının tamamının cümle ya da paragraflardan oluştuğu, bağımsız metin özelliği gösteren liste, grafik, tablo vb. ile ilgili hiç soru sorulmadığı görülmektedir.

Tablo 2 : 2016-2017 Eğitim Öğretim Yılı II. Dönemi 8. Sınıf Türkçe Dersi Merkezî Sınav Sorularının Metin Türlerine Göre Dağılımı

\begin{tabular}{l|c|c}
\hline \multicolumn{2}{c}{ Soru Analiz Listesi 1 } & \% \\
\hline Metnin Türü & $\mathbf{f}$ & 13.33 \\
\hline Betimleme & 2 & 26.66 \\
\hline Hikâye & 4 & 13.33 \\
\hline Açıklama & 2 & 40 \\
\hline Tartışma & 6 & 6.66 \\
\hline Şiir & 1 & - \\
\hline Yönerge & - & \\
\hline
\end{tabular}

Tablo 2 incelendiğinde, 8. Sınıf Türkçe Dersi Merkezî Sınav Sorularının yarısına yakınının tartışma türündeki ikna ve fikir yazıları olduğu ( 2-4-5-7-9-12. sorular) tespit edilmiştir. Soruların dördünün olaya dayalı metin olduğu ( 11-11-14-15. sorular), ikisinin betimleyici özellikler taşıdığı (3-6. sorular), yine iki sorunun bilgi aktaran açıklama türünde metin olduğu (10-13. sorular), bir metnin şiir türünde olduğu (8. soru) görülmektedir. Yönerge türünde ise herhangi bir soru sorulmamıştır.

Tablo 3 : 2016-2017 Eğitim Öğretim Yılı II. Dönemi 8. Sınıf Türkçe Dersi Merkezî Sınav Sorularının Okuyucunun Metne Yaklaşımına Göre Dağılımı

\begin{tabular}{|c|c|c|c|c|c|c|}
\hline \multicolumn{7}{|c|}{ Soru Analiz Listesi 3} \\
\hline \multirow{2}{*}{ Düzeyler } & \multicolumn{2}{|c|}{$\begin{array}{l}\text { Bilgiye Ulaşma ve } \\
\text { Bilgiyi Hatırlama }\end{array}$} & \multicolumn{2}{|c|}{$\begin{array}{c}\text { Bilgiyi Bir Araya Getirme } \\
\text { ve Yorumlama }\end{array}$} & \multicolumn{2}{|c|}{$\begin{array}{c}\text { Kendi Düşüncelerini Yansıtma } \\
\text { ve Metni Değerlendirme }\end{array}$} \\
\hline & $\mathbf{f}$ & $\%$ & $\mathbf{f}$ & $\%$ & $\mathbf{f}$ & $\%$ \\
\hline \multicolumn{7}{|l|}{$\mathbf{1 b}$} \\
\hline $1 \mathbf{a}$ & 1 & 50 & 3 & 27.27 & & \\
\hline 2 & 1 & 50 & 3 & 27.27 & 2 & 100 \\
\hline 3 & & & 5 & 45.46 & & \\
\hline \multicolumn{7}{|l|}{4} \\
\hline \multicolumn{7}{|l|}{5} \\
\hline 6 & & & & & & \\
\hline
\end{tabular}

Tablo 3 incelendiğinde, , 8. Sınıf Türkçe Dersi Merkezî Sınav Sorularının yaklaşık dörtte üçünün bilgileri bir araya getirme ve yorumlama yaklaşımı ile sorulduğu, bilgiye ulaşma ve hatırlama ile kendi düşüncelerini yansıtma ve metni değerlendirme yaklaşımlarından ikişer soru sorulduğu tespit edilmiştir. 8. Sınıf Türkçe Dersi Merkezî Sınav Sorularının düzeylerine baktığımızda soruların 1a, 2 ve 3. düzeylerde yoğunlaştığ $;$; 5 ve 6 . düzeyleri ölçebilecek soruların sorulmadığı görülmektedir. 


\section{Tartışma ve Sonuç}

Araştırmanın sonuçları aşağıda belirtilmiştir:

- 2016-2017 Eğitim Öğretim Yılı II. Dönemi 8. Sınıf Türkçe Dersi Merkezî Sınav Sorularının metnin sunulma şekli açısından dağılımında tüm soruların akıcı metin özelliği gösteren cümle ya da paragraflardan oluştuğu tespit edilmiş olup bağımsız metin olabilecek liste, grafik, tablo içeren herhangi bir soruya yer verilmemiştir.

- 2016-2017 Eğitim Öğretim Y1lı II. Dönemi 8. Sınıf Türkçe Dersi Merkezî Sınav Sorularından 11 tanesinin tartışma türündeki ikna ve fikir yazıları olduğu, 4 sorunun olaya dayalı metin olduğu, 2 sorunun betimleyici ve 2 sorunun da bilgi aktaran açıklama türünde metin olduğu, 1 metnin şiir türünde olduğu tespit edilmiştir. Yönerge içerikli ise herhangi bir soru sorulmamıştır.

- 2016-2017 Eğitim Öğretim Yılı II. Dönemi 8. Sınıf Türkçe Dersi Merkezî Sınav Soruları okuyucunun metne yaklaşımı açısından sınıflandırıldığında 2 sorunun bilgiye ulaşma ve hatırlama boyutunda yer aldığı, 11 sorunun bilgileri bir araya getirme ve yorumlama boyutunda olduğu ve 2 sorunun da kendi düşüncelerini yansıtma ve metni değerlendirme boyutunda olduğu tespit edilmiştir.

- 2016-2017 Eğitim Öğretim Y11ı II. Dönemi 8. Sınıf Türkçe Dersi Merkezî Sınav Soruları okuma beceri düzeyleri açısından değerlendirildiğinde en alt düzey olan 1 b düzeyinde soru olmadığ 1 , 1a düzeyinde 4 soru olduğu, 2. düzeyde 6 soru olduğu ve 3 . düzeyde 5 soru sorulduğu tespit edilmiştir.

- 2016-2017 Eğitim Öğretim Yılı II. Dönemi 8. Sınıf Türkçe Dersi Merkezî Sınav Sorularının okuma becerileri düzeyleri açısından incelendiğinde soruların hiç biri 4, 5 ve 6 . düzeyleri ölçmemektedir.

Savran (2004), 2003 yılında yapılan PISA araştırmasındaki okuma becerileri, matematik ve fen alanlarındaki üç sorunu örneğini incelediği araştırmasında, PISA'da sorulan soruların ülkemizde yapılan sınav soruları ile örtüşmediğini tespit etmiştir.

Aşıcı, Baysal ve Şahenk (2012), tarafından yapılmış olan çalışmada, 2009 SBS soruları ile PISA 2009 okuma becerileri soru tipleri karşılaştırılmıştır. Araştırma sonucunda, 2009 SBS sorularının çoğunlukla kişisel metin türünde olduğu, okuyucunun metne yaklaşımı açısından bilgiyi bir araya getirme ve yorumlama boyutunda olduğu tespit edilmiştir. Ayrıca 2009 SBS sorularının PISA okuma yeterlikleri açısından 2, 3 ve 4. düzeyde oldukları ve 2009 SBS'de PISA'nın üst düzey olan okuma becerilerinden 5 ve 6 . düzeyde soru bulunmadığı belirlenmiştir.

Batur ve Ulutaş (2013) tarafından yapılan çalışmada, 6-8. Sınıflar Türkçe Öğretimi Programı'nda yer alan okuma becerisi kazanımlarının PISA testinde tanımlanan okuma becerisi düzeylerini kapsama düzeyleri incelenmiştir. Çalışma sonunda, 2006 İlköğretim Türkçe Dersi (6, 7, 8. Sınıflar) Okuma Becerisi Kazanımlarının elli bir tane olduğu görülmüş, bunlardan yaklaşık on sekizinin PISA'nın alt düzeydeki okuduğunu anlama yeterliliklerine denk geldiği görülmüştür. Türkçe dersi okuma becerisi kazanımları arasında PISA'nın 5 ve 6. düzeyleri ile doğrudan örtüşebilecek açıklamalar bulunmadığı buna bağlı olarak da öğrencilerin bir üst düzeye çıkamadığı tespit edilmiştir.

İnce (2016), PISA'da yoklanan okuma becerileri yeterlilikleri ile ortaokul Türkçe öğretim programındaki kazanımların karşılaştırılmasına yönelik yaptığı çalışmada, PISA okuma becerileri yeterliklerinden bir, iki ve üçüncü düzeyler ile Türkçe öğretim programının örtüştüğü belirtilmiştir. Ancak PISA'da yer alan üst düzey yeterliklerle programda belirtilen okuma alanı ile ilgili kazanımların yaklaşık yarısından fazlasının örtüşmediği sonucu tespit edilmiştir. Ayrıca araştırma sonucunda Türkçe ders kitabında yer alan metinlerin farklı çeşitlilikte olmadığı ağırlıklı olarak hikâye türünde olay yazılarının yer aldığı ve ders kitaplarında form, grafik, liste, şema, plan, katalog, tablo gibi kullanmalık metinlerin olmadığı görülmüştür.

2015 yılında yapılan son PISA araştırmasına göre ülkemizde temel eğitimin sonuna gelmiş örgüm eğitim içindeki 15 yaş grubundaki öğrencilerden okuma becerileri değerlendirme çerçevesinde en üst düzeyde başarı gösteren öğrenci oranı \% 1 kadardır. 6 . yeterlik düzeyi olarak kabul edilen bu düzey, metnin içinde verilen açık olan bilgileri ve bunun ötesinde metinde açık olarak belirtilmemiş bilgileri, iletileri ve durumları çözümleyerek metni anlamayı ve yorumlamayı gerektirmektedir. Aynı zamanda bu yeterlik düzeyi, gelişmiş ülkeler tarafından bilgi birikimi açısından üzerinde durulan bir ölçüttür. İçerik ve yapı olarak çeşitli farklılıklar içeren metinlerin çözümlenmesinin hedeflendiği 5. yeterlik düzeyinde ise ülkemizdeki başarı oranı \%5.7'de kalmıştır. OECD ülkeleri ile karşılaştırıldığında bu oran OECD ülkelerindeki başarı düzeyinin dörtte birine denk gelmektedir. Bilgi ve kavrama düzeyini ifade eden 1. ve 2. yeterlik düzeyinde ise ülkemizdeki öğrencilerin yaklaşık \%72,6'sı bulunmaktadır. Bu temel yeterlik düzeyi olarak kabul edilen düzeyden daha üst düzey becerilere öğrencilerimizin büyük bir çoğunluğunun çıkamadığg görülmektedir.

Temel eğitimin sonuna gelmiş ya da bitirmiş dünya genelindeki 15 yaş grubu öğrencileri bir okuyucu olarak ne kadar yeterliğe sahip ve neler biliyorlar? Metinlerden kendi ihtiyaçları doğrultusunda bilgileri tespit ediyor, 
yorumluyor ve ihtiyacına göre bilgiyi kullanıyor mu? Kendi tecrübe ve yaşantısı doğrultusunda metin hakkında eleştirel bir anlayış getirebiliyor mu? İlgilerine ve isteklerine göre veya çeşitli sebeplerden ötürü, yazılış amacı farklı ve değişik olan ve içeriğinde farlılıklar bulunan metinleri okuyabiliyor mu? (MEB, 2010). Bu sorulara, PISA araştırması okuma becerileri alanı değerlendirme çerçevesi kapsamında cevap aranmakta ve bu noktada Türkçe Öğretim Programı da bu sorulara cevap aramakta ve okuma becerilerinin kazandırılmasını hedeflemektedir. Hedeflenen bu becerilerin ölçme ve değerlendirilmesi için yapılan 8. Sınıf Türkçe Dersi Merkezî Ortak Sınavı'nın hayat boyu öğrenme ve okuryazarlık kavramları etrafında hazırlanması buna uygun şekilde değerlendirilmesi gerekmektedir. Böylece, öğrenciler hem ülke düzeyinde hem de uluslararası düzeyde üst düzey okuma becerilerine sahip olacaklardır.

Yapılan son PISA araştırmasında okuma becerileri alanında ve temel eğitimden ortaöğretime geçişte büyük bir paya sahip 8. Sınıflar Merkezi Sınavlarda Türkçe dersindeki öğrencilerin üst düzey okuma becerileri yeterlikleri düşünüldüğünde okuryazarlık becerilerinin öğrencilerde eksik olduğunu göstermektedir. Türkçe Öğretim Programı ile ilgili görüşlerini açıklayan Batur ve Ulutaş, "Okuma alanında verilen okuma alışkanlığı kazandırmaya yönelik kazanımların okuduğu metni anlama ve yorumlamaya doğrudan katkı sağlamamaktadır." (2013) şeklindeki ifadeleri durumu özetlemektedir. Börekçi'nin, "Sözlü ve yazılı anlatım süreçlerinin bilinçli bir seçme birleştirme gerektirdiği; anlama sürecinin de çözümleme ile analiz edilmesi ve dinleme, okuma ile konuşma, yazma faaliyetlerinin dilbilim kuramları çerçevesinde yürütülmesi ve uygulanması gerekir."(2015) şeklindeki önerisi Türkçe öğretiminde bilimsel bir yaklaşımın uygulanması gerektiğini zorunlu kılmaktadır.

\section{Öneriler}

Elde edilen sonuçlar, yapılan araştırmalar ve tartışmalara göre çalışma sonunda, Türkçe eğitimi ile ilgili tüm kişilere önerilerimiz şunlardır:

- Temel eğitimden ortaöğretime geçişte büyük bir payı olan 8. Sınıf Türkçe Dersi Merkezî Ortak Sınavı hayat boyu öğrenme ve okuryazarlık kavramları etrafinda hazırlanmalı ve bu uygun değerlendirilmelidir.

- 8. Sınıf Türkçe Dersi Merkezî Ortak Sınavı'nda metinlerin çeşitliliği artırılmalı, bağımsız şekilde sunulan liste, grafik, tablo gibi metinlerin yanı sıra karışık sunulan akıcı ve bağımsız metinlerin bir arada olduğu metinlere yer verilmelidir.

- 8. Sınıf Türkçe Dersi Merkezî Ortak Sınavı'nda metin türleri belirlenirken günlük hayatta kullanılabilecek yönerge, kullanım kılavuzu, bilimsel yazılar, haber yazıları, Genel Ağ günlükleri, elektronik posta yazışmaları, kavram haritaları gibi metinlere de yer verilmelidir.

- 8. Sınıf Türkçe Dersi Merkezî Ortak Sınav soruları hazırlanırken okuyucunun metne yaklaşımı açısından bilgiye ulaşma ve bilgiyi hatırlama ve kendi düşüncelerini yansıtma ve metni değerlendirme yaklaşımlarına yönelik soruların az olduğu da dikkate alınarak uygun bir soru dağılımı sağlanmalıdır.

- 8. Sınıf Türkçe Dersi Merkezî Ortak Sınav soruları okuyucunun metne yaklaşım düzeylerine göre basitten zora doğru düzenlenmeli ve özellikle 5 ve 6 . düzeylerde hazırlanmış sorulara da yer verilmelidir.

- 8. Sinıf Türkçe Dersi Merkezî Ortak Sinav sorularına dayanak oluşturan Türkçe öğretim programındaki beceriler öğrencilere kazandırılırken dil eğitimi yalnızca basit dinleme, okuma, konuşma ve yazma eğitimi olarak değerlendirilmemeli; çok yönlü bir düşünme faaliyetinin sonunda ortaya çıkan ve dil düşünme ilişkisi içinde dilbilimsel bir inceleme alanı olarak görülmelidir.

- 8.Sınıf Türkçe Dersi Merkezî Ortak Sınav soruları; bilgiyi yorumlama, akıl yürütme becerilerini kullanma, bilgi ve becerileri gerçek hayata aktarabilme, eleştirel ve analitik düşünebilme, açık uçlu cevaplarla düşünceleri ifade edebilmeye uygun olarak hazırlanmalıdır.

- 8.Sınıf Türkçe Dersi Merkezî Ortak Sınav soruları hazırlanırken kullanılacak metinler karşılaştırma ve kıyaslamaya uygun, öğrencinin kendi yaşam deneyimi ile ilişkili ve anlamını, iletisini içinde gizleyen şekilde sunulmalıdır.

\section{Kaynakça}

Aşıc1, M., Baysal, Z. N., Şahenk Erkan S.S. (2012). Türkiye'de Yapılan 2009 PISA ve Seviye Belirleme Sınavındaki (SBS) Okuma Becerileri Sorularının Karşılaşıııılması, Eğitim ve Öğretim Araştırmaları Dergisi, May1s, Haziran, Temmuz 2012, C.1, S.2 2146-9199.

Batur, Z. ve Ulutaş M. (2013). PISA ile Türkçe Öğretim Programındaki Okuduğunu Anlama Kazanımlarının Örtüşme Düzeyinin İncelenmesi, Journal Of Academic Social Studies Jass, Volume:6, Issue:2, 15491562.

Börekçi, M. (2015). Bir Bilim Alanı Olarak Türkçe ve Türkçe Eğitimi, Erzincan Üniversitesi Sosyal Bilimler Enstitüsü Dergisi ÖSII, 405-414. 
Dilidüzgün, Ş. (2008). Türkçe Öğretiminde Metindilbilimsel Bağlamda Uygulamall Bir Yaklaşım. Yayımlanmamış Doktora Tezi, İstanbul Üniversitesi, Sosyal Bilimler Enstitüsü.

İnce, M. (2016). Türkçe 6, 7, 8. Sinı Öğretim Programının Uluslararası Öğrenci Değerlendirme Programı'nda (PISA) Yoklanan "Okuma Becerileri" Açısından Analizi (Zonguldak Örneği), Yayımlanmamış Doktora Tezi, Ankara Üniversitesi, Eğitim Bilimleri Enstitüsü.

Karasar, N. (2012). Bilimsel Araştırma Yöntemi, Ankara: Nobel Yayıncılık.

Kocaman, A. (1996). Türkçe Öğretiminde Kullanım Düzlemi Üzerine Düşünceler, Çağdaş Türk Dili Dergisi, Sayı:100, s. 28-31.

MEB. (2010). Uluslararası Öğrenci Değerlendirme Programı PISA 2009 Ulusal Ön Raporu. Ankara

MEB. (2014). 2014-2015 Öğretim Yılı Ortak Sınavlar e- Kılavuzu. Ankara.

MEB. (2015 a). Uluslararası Öğrenci Değerlendirme Programı PISA 2012 Ulusal Nihai Raporu. Ankara.

MEB. (2015 b). Türkçe Dersi (1-8. Sınıflar) Öğretim Programı. Ankara.

MEB. (2016). Uluslararası Öğrenci Değerlendirme Programı PISA 2015 Ulusal Raporu. Ankara.

MEB. (2017). Türkçe Dersi İlkokul ve Ortaokul (1-8. Sınıflar) Taslak Öğretim Programı. Ankara.

Savran, N. Z. (2004). PISA Projesinin Türk Eğitim Sistemi Açısından Değerlendirilmesi, Türk Eğitim Bilimleri Dergisi, Gazi Üniversitesi, 2(4), 397-412.

Yıldırım, A. ve Şimşek, H. (2011). Sosyal Bilimlerde Nitel Araştırma Yöntemleri. (8. Basım). Ankara: Seçkin Yayınları.

\section{Extended Abstract}

What is the qualification and what do they know as a reader of 15 age group students worldwide who have reached the end of basic education or have finished their basic training? Do these students identify, interpret, and use the information according to their needs from the texts? Can students bring a critical understanding of the text in line with their experience and life? Can these students read texts based on their interests and wishes, or for various reasons, the purpose of the spelling is different and varied and has differences in its content? These questions are sought to answer within the scope of the evaluation framework of the field of reading the PISA research skills. In fact, the Turkish curriculum seeks answers to these questions and aims to provide students with reading skills. The eighth-grade Turkish course needs to be prepared and evaluated in accordance with the concepts of the central joint exam around lifelong learning and literacy. Thus, students in Turkey will have high-level reading skills both at the country level and at the international level.

In the final PISA research, the qualifications of the students who have been tried to be measured with the questions in the field of study in the field of reading skills and the eighth-grade center exams are considered together with their high level reading skills. The students in Turkey show that literacy skills are lacking. It is emerging as a result of researches made in the Turkish curriculum that does not contribute directly to the reading and interpretation of the texts read in the field of literacy. Therefore, all areas of Turkish should be applied in the language education of an inclusive linguistic approach.

This research is not actually a comparison of the PISA project and the eighth-grade central joint exams. A qualification analysis was made according to the evaluation tools developed through the texts and questions of the exams, which are different from the purpose and characteristics of the tests. The characteristics of the texts in the internationally accepted Pisa research were determined to determine the qualifications of the central Joint Exam questions of the eighth grade Turkish course based on the qualifications of the evaluation framework and the reading skills.

The aim of the research is to show how the central exam questions of the eighth grade Turkish course applied in the transition from basic training to secondary education are appropriate for the proficiency levels of the reading skills in the PISA research. As a result of this research, the eight-class central joint exam, attended by hundreds of thousands of basic education senior students from the same age group as the PISA exam, will provide data on education policy and status throughout the country. intended to put forth.

In this study, the 2016-2017 academic year II, which was last performed in eighth-grade central joint exams since 2013. Fifteen questions were examined as documents, and questions were analyzed in accordance with the evaluation tools and expert opinions in the eighth grade Turkish course central exam in the period. The questions 
in the joint exams conducted in other years have not been taken into consideration by measuring the same gains and skills as the joint exam held in the last year.

As a result of the study, 2016-2017 academic year II. Semester eighth grade Turkish lesson Central Exam questions in terms of the presentation of the text of the distribution of all the questions that indicate the fluency of text is determined to consist of sentences or paragraphs, which can be independent text list, chart, table containing No questions were given. Eleven questions in this test are the type of persuasion and ideas of discussion. Four questions are questions about an event-based text type. The two questions are the descriptive text type. The two questions are questions of the type of description that convey the information. A text is found to be a type of poetry. If the directive is content, no questions are asked. When the questions are classified in terms of the reader's approach to text; The two problems were found to be in the size of information and recall. Eleven is at the level of gathering and interpreting the information of a problem. The two problems were determined to reflect their own thoughts and to the level of evaluation of the text. When questions are assessed in terms of reading skill levels; There is no level $1 \mathrm{~b}$ question at the lowest level. There are four questions at level 1a, there are six questions on the second level, and there are five questions on the third level. However, there is no question that measures the fourth, fifth, and sixth levels.

At the end of the study, according to the results obtained, research and discussions, our recommendations for all persons related to Turkish education are as follows: the central joint exam of the eighth grade Turkish course is centered around the concepts of lifelong learning and literacy must be prepared and evaluated accordingly. The diversity of texts should be increased in the eighth-grade Turkish course, and the texts, such as the list, chart, table, and texts that are presented in mixed form, must be included in the text of a mixture of fluid and independent texts. In this examination, texts such as instruction, user manual, scientific writings, news articles, general network logs, e-mail correspondence, concept maps, etc. can be used in daily life. As these exam questions are prepared, a suitable question distribution is given to the reader's approach to the text and to remember the questions and to recall the information and to reflect their own thoughts and evaluate the text. Ensured. The test questions should be arranged from simple to difficult according to the reader's approach to text, and especially the fifth and sixth. Should also be included in the questions prepared at the level. While the skills in the Turkish curriculum that constitute the basis for the central joint exam questions are given to students, language education should not be considered as simple listening, reading, speaking and writing education; It should be seen as a linguistic examination area in the end of a multi-faceted thinking activity and in the language thinking relationship. Common exam questions; It should be prepared in accordance with interpreting information, using reasoning skills, transferring knowledge and skills to real life, thinking critically and analytic, and expressing thoughts with openended answers. The texts to be used in preparation of these exam questions should be presented in a manner that is appropriate to compare and comparison, and that the student is associated with his or her life experience and that it is hidden in the message. 